\title{
THE CHALLENGE TO INDUSTRIAL FORESTRY
}

\author{
By ThOMAS G. WRIGHT ${ }^{1}$
}

\author{
Alssociate Professor of Forestry, University of British Columbia, \\ Vancouver, British Columbia
}

$\mathrm{T}$

ODAY'S INDUSTRIAL forester has one of the greatest opportunities in the forestry profession. He stands at the threshold of a new era in forestry, and upon his shoulders rests the responsibility for demonstrating that private enterprise can manage our forests with skill and efficiency.

The awareness of the timber industries to their forestry problems is demonstrated by their decision to engage foresters on their staffs. In hiring professional men to direct their forestry programs, the companies have tossed the ball to the foresters to establish the foundations of industrial sustained yield.

Starting as he does with unmanaged properties, the forester faces a difficult task. His information on timber inventory is far from complete. His estimates of growth and yield are sketchy, at best. His knowledge of the correct application of silvicultural techniques is quite imperfect. Fire protection planning and organization have a long way to go. The men in the woods must be educated into accepting forest management as a necessary part of field operations.

Although these tasks of building a forestry program from the ground up might seem to be too difficult, they actually constitute a challenge and an opportunity which seldom have been equalled in the history of the forestry profession.

Basically the odds are all with us. We have a vast acreage of productive forest land, a great timber resource, and a huge domestic and world market for our products. We have the machinery and manpower to do an effective job on a large scale.

The company forester has the advantage of being backed by the efficient methods of modern industry. As a member of an organization which is conducting logging operations, he has a particularly fine opportunity to practise his profession in the woods.

It is important that the industrial forester remember these many advantages, and not get bogged down in unproductive side channels. He must keep his feet in the brush and his eyes on the timber if he is to render the greatest long-term service.

It is easy to waste time on the never-ending debate on forest policy. As long as there is a forestry profession there will exist a legitimate debate about forest ownership, forest regulation and forest taxation. These are important matters which require constant adjustment and re-appraisal. They are issues on which men will never agree because of differences in political

1. The author is also Consulting Forester for Canadian Forest Products, Limited. He prepared British Columbia's first industrial sustained yield plan when he was Consulting Forester for Bloedel, Stewart and Welch, Limited, from 1941 to 1943 . In 1946 he was engaged in a survey of growth and yield by the Powell River Company. 
viewpoints, personal philosophy, and organizational loyalty. They are issues which, under democracy, are adjusted by compromise. They are issues to which every forester must give serious attention, but he must not allow them to divert him from attacking the physical problems of forestry in the woods.

It is an error to think that until these things are settled, the forester cannot go ahead with forestry.

Have not the dirt foresters contributed the most to our profession in the past? Forest engineers have made the timber accessible. The men who have built volume and yield tables have made a substantial contribution. The men who have given their efforts to the cause of fire protection have made their indelible mark. The men who cruised the timber and made the maps have provided the essential cornerstones of forest management. Men of both government and industry have contributed to this progress.

Only when our ideas on policy are built on a common foundation of dirt forestry can we come to the most effective compromises as to the type of laws and regulations that will further the aim of good forestry. Only then can we make existing laws really work in the woods. When our thinking on matters of policy is dictated by vague economic theories, or by a desire to "pass the buck" to the other fellow, then the arguments grow louder and forestry stands still.

The famous forestry laws of Sweden were a logical outcome of agreement by foresters that a constructive program must be workable in the woods.. The great Swedish laws of 1903 and 1923 made it compulsory that every acre logged be restocked and that young forests be allowed to reach maturity before they could be clear-cut. These laws were established because foresters stood together on basic forestry principles. The laws have worked because foresters made them work. Indeed, the industrial forester of Sweden sets such a high standard of silvicultural practice that the government rarely finds it necessary to enforce the regulations.

Good industrial forestry does not mean poor government forestry, or vice versa. During the writer's army experience in Europe he was impressed by the excellence of both government and private forestry. On this continent many examples of good and poor forestry can be cited by both sides. Constructive forestry by the companies will make the job of govern. ment foresters all the easier, and will do much to cement the spirit of co. operation and goodwill between industry and government. It will stimulate a constructive spirit of rivalry. If the government forester or the industrial forester is out to prove that his type of practice is best he must prove it by deeds, not words.

We have reached a stage in the forestry profession where we can no longer say that it is up to the government, or the industry, or anyone else, to do certain things before we can go ahead. It is a negative attitude to say: "Our hands are tied until the government changes the tax structure on forest lands". Or, "Until the ownership pattern is changed in our favour, we refuse to budge". These arguments are poor excuses for non-stocked acres and mis-managed properties. 
The success of forest policy depends more upon foresters themselves than upon any other group. If we have the will and the spirit to unite toward a common objective, then we shall more quickly reconcile our differences of method and convert the skeptics. to our side.

The old evangelistic conviction that we must practise forestry, the odds be damned, will win more supporters than the most painstaking, erudite analyses of where the sphere of government ends and the sphere of industry begins.

A forester is not furthering forestry if he feels it is his job to be a "front man". It is possible by publicity methods to exaggerate the favorable results of past and present forestry efforts. Indeed, it is quite possible through "public relations" to convey the idea that any shortcomings in forest practice are the responsibility of government or someone else.

The main thing wrong with this type of public relations is that it does not grow trees. Public relations cannot take the place of dirt forestry.

We all know that strong public relations efforts are necessary to win public support. But it is sometimes forgotten that the most powerful of our public relations weapons is forestry itself. We can win the greatest support by pointing to the successful application of our handiwork in the woods.

Can we afford to practise forestry? It is easy to get drawn into arguments which end in blind alleys when we attempt to answer this one. If we accept the premise that there is a mathematical answer to this question, then we let ourselves in for a debate which leads only to a welter of statistics and disagreement.

Sometimes it is asserted that industry will demand complete dollars and cents "proof" that "forestry will pay" before it embarks on a full scale program. This idea parallels the impression that business can calculate precise returns in advance before embarking on new ventures.

What business can predict with certainty its future costs and returns? Many of today's great timber enterprises were built by men who "took a chance", investing their savings and throwing their efforts into the uncertainties of the lumber business. It is true that industry calculates the risk as closely as possible. But in business as elsewhere vision and imagination are required to translate calculated risks into action.

Who can predict markets for forest products for a year in advance, let alone a cutting cycle or a rotation in the future? Who can prove what the future pattern of utilization will be? Who knows for certain what will be the future costs of wages and materials? Who knows which areas will be "accessible" and which will be "inaccessible" in the years ahead? Who knows what will happen in international trade and domestic economics?

The real issue is this: Can we afford not to practise forestry? Dare we risk the future of a major industry on an uncertain supply of raw materials? Dare we risk the productive potential of a vast area of land on the possible outcome of vague calsulations as to whether or not forestry will pay? 
We might as well ask: Can we afford to educate our children? If we as foresters are not convinced that forestry will pay, how can we expect to convince anyone else? Have we any choice but to "take a chance" on forestry?

We are entitled to believe that engineering and technical advancements will only assist us in our goal of better forestry. We know that the demand for stumpage is greater today than ever before, and we have a right to expect this demand to continue.

We know that society is going to require that we do a constructive job in the woods. The critics of industry are always prepared to point to what they consider to be shortcomings in responsibility toward the public interest. Let us be prepared to demonstrate that any critics of private forestry are dead wrong. We shall stand in a better position in our dealings with government if we have a solid foundation of good works to stand upon.

The forestry profession needs men who are prepared to re-examine the old ideas and think for themselves. Our silvicultural and management conceptions are clouded with vague generalities and platitudes which need careful re-checking in the field. So many of our ideas are influenced by our rough and ready methods of forestry in the past. Many of our theories have not been tested or proved in practice. Other theories will apply in one place, but not in another. Viewpoints formerly considered theoretical and academic may, upon re-examination, prove to be quite useful.

Changing economic conditions will require that we change many of our old ideas. Increasing markets for inferior species and for formerly "waste" ma. terials are already pointing to wonderful new horizons of silviculture.

If we examine stands of timber on the ground, attempting to discover why they grew as they did, we may find causes and effects which never had occurr. ed to us. If we compare different areas with one another on their merits, instead of upon the basis of traditional conceptions, we will find our prac. tical knowledge of management increasing rapidly. A clear, open mind will be a great asset in moving quickly toward the era of intensive management.

The most successful forester will be marked by his inquiring attitude of research. E. P. Stamm of the Crown Zellerbach Corporation explained his conception of research as a "willingness to try any fool thing any darn fool suggests". The forester who is willing to stick his neck out and make mistakes will contribute more to the ultimate progress of his profession than the man who passes the responsibility for things "new and different" to the other fellow.

The forestry profession does not need the type of man who, posing as a "hard-boiled, practical fellow", asserts that economic conditions, combined with realistic conditions of logging, make it foolish to attempt practices other than those currently employed. The so-called "practical" man is a handicap to the forestry profession. The men who have made history have been men with ideals and convictions. The forester who does not have an unswerving belief in forestry is in the wrong profession. 
In working on West Coast logging operations the writer invariably has found that the keenest interest in dirt forestry has been exhibited by the men who are truly practical--the men who have the responsibility for manag. ing the woods operations.

The industrial forester of the future will make his mark by his achieve. ments in the woods.

He will not be the man who created the widest barrier between indus. trial and government foresters. He will not be the man who proved on paper that the forest industries cannot really practise forestry because of the tough competitive situation in which they find themselves.

The successful company forester will be proud of the completeness of the restocking on every acre logged by his company. He will point to the highball protection system established under his leadership. He will be proud of the completeness of his maps, and of the accuracy of his estimates on growth and yield.

The forester extraordinary will have an intimate knowledge of every corner of his company's holdings. He will have a reputation for the thoroughness of his scientific field technique. He will be skilled in applying practical silviculture on the ground. He will have the respect of the men in the woods who have been sold on forestry by the logic and persuasiveness of the forester himself.

Basically, the challenge to government and industrial foresters is identical. Their task is to grow trees. 